\title{
One Year is Not Enough to Adapt with a New Traditional Culture: Looking into the Cultural Heritage Elements and Practices Among Immigrants in Malaysia
}

\author{
Nasir Yusoff ${ }^{1}$, Hue San Kuay, Sabarisah Hashim and Faruque Reza \\ Universiti Sains Malaysia
}

\begin{abstract}
Adapting to a new traditional cultural environment has noteworthy implications for emotional manifestations, especially among immigrants who migrated to a new place. This study aimed to examine the effect of living duration (one-year cut-off period) among immigrants in Malaysia on their emotional manifestation towards the traditional culture of the ethnic majority. This study also examined the element of cultural items (games, clothes, or food) most affected during their adaptation in the new traditional culture environment. About 119 international graduate students (male; $n=72,61 \%$ ) from a public university in West Malaysia who met the inclusion criteria took part in this cross-sectional study. They were selected using convenient sampling method. Using visualisation approach, two groups of immigrants with different living duration (less than a year versus a year or more) were asked to respond to the pictures of Malay traditional items (traditional food, game and clothes) that were projected onto the screen. While viewing the pictures, participants rated their emotional state of valence from one (low valence/high pleasantness) to nine (high valence/high pleasantness) according to the non-verbal pictorial measure of Self-Assessment Manikin Scale. Socio-demographic and acculturation scores were also collected. The study found the one-year duration of living in the country as insufficient for the immigrants to adapt to the new cultural environment. Traditional food seems to be the most affected cultural item. The tendency of immigrants to practice the Malay tradition explained $4 \%$ of the variance of immigrants' emotional manifestation towards Malay traditional food. To conclude, the duration of living in a country is crucial to adapt to a new traditional culture. Unsurprisingly perhaps, traditional food in the particular country brought more emotional property than other cultural items.
\end{abstract}

Keywords: cultural heritage, emotion, immigrant, traditional culture, valence.

\section{Malay Tradition}

Malays are the ethnic majority in Malaysia, comprising more than $50 \%$ of its entire population of the country (Department of Statistics Malaysia, 2020). Most of them can be found living in the West (Peninsular) Malaysia region, although some of them live in Sumatra Indonesia and Borneo island and even as far as the Australian continent. Historians believe the Malay

${ }^{1}$ Corresponding Author E-mail: nasirff@usm.my 
ethnicity branched out across Austronesia spreading from West Malaysia to Sumatra Indonesia and covering southern parts of Thailand (Milner, 2010). However, small Malay clusters different in language, tradition, and genetics are scattered in Southeast Asia due to migration and assimilation (Barnard, 2004; Milner, 2010).

The Malay culture started blooming rapidly during the golden age of the Malaccan Sultanate in the $15^{\text {th }}$ century as a result of prosperity at the economic activity in Malacca that was a progressive trading centre at that time (Alexanderll, 2006; Wolters, 1999). This activity indirectly spread the Malay culture among foreign traders who came for trading, and marriage between foreign traders and the locals further spread the Malay culture from generation to generation. Around the $12^{\text {th }}$ century, Islam came to the Malay and began influencing their way of life. Later, the Hindu religion influenced the culture of Malays due to encounters between two cultures from their migration to Malaya during the British colonisation (Akhbar, 2010; Halimi, 2008; Othman, 2002; Punitha \& Kumaran, 2014; Rostam, 1984; Shafie \& Zainudin, 2000).

Today, the identity of Malay ethnicity is evident, especially in the aspects of food, clothing and games. Food such as ketupat palas is a Malay traditional food that is recognised as a national heritage (Department of National Heritage Malaysia, 2020). Ketupat palas is a type of glutinous rice wrapped around the leaves of fan palm (Licuala) and is usually served together with chicken or beef curry during Islamic festivals or celebration such as Eid Al-Adha and Eid Al-Fitr. Today, ketupat palas can be found easily in markets and is served as a delicacy in normal events (celebration). This traditional food is believed to have existed for aeons and is found in literature like the story of Indraputra.

Among other elements of culture listed as a national heritage is a game called sepak raga (Department of National Heritage Malaysia, 2020), which is a favourite game among the Malays. Some believe that sepak raga existed 600 years ago in the era of the Malaccan Sultanate in the $15^{\text {th }}$ century. This game is a favourite of every layer of the community regardless of gender and age, which is seen from the support from the Malay community towards the game in every competition that is held. During the game, the players form a circle, and they kick the ball with their legs or hit it with their head so that the rattan ball does not fall or touch the ground. Today, as a result of modernisation and urbanisation, the game has undergone several changes such as the use of nets that separate players into two groups (Department of National Art and Culture, Malaysia, 2019).

Malay traditional clothes such as Baju Melayu (for men) and Baju Kebaya (for women) are also among the national heritage recorded by the Department of National Heritage (Department of National Heritage Malaysia, 2020). Baju Kebaya is usually worn by Malay women in Southeast Asia in Malaysia, Indonesia, Singapore and Brunei. It is believed that the Baju Kebaya was adopted as an official garment from Java Islands around 1600 during the Dutch colonisation. Nonetheless, the Baju Kebaya has not been spared from outside influence. The designs of Вaju Kebaya has evolved over generations. The tradition of the Arabs known for its clothes which is Abaya was brought into Malay land by the merchants are believed to have influenced the patterns and designs of Baju Kebaya. Today, Baju Kebaya is available in a variety of patterns matched with a batik sheath and songket. The beauty of its stunning cut of the pattern has made it a uniform in tourism sectors, including the national airlines. Similarly, Malay men often wear Bajи Melayu in Malaysia and Indonesia. Baju Melayu is often matched with sampin (from songket cloth) and an oval cap (songkok) which is worn especially during the Muslim festivals such as Eid al-Fitr and Eid alAdha (Fuller, 2000; Ihsan, 2009). 


\section{Immigrants in Malaysia}

Immigrants in Malaysia are a non-Malaysian social group who migrated to Malaysia for a variety of reasons, especially for studying and working (Department of Malaysian Immigration, 2016). They live in Malaysia for a while before returning to their home countries. Their presence in Malaysia has created encounters between their culture and that of the place of their migration. The situation requires this group of immigrants to adapt to the local culture where they are living. From a sociological perspective, this cultural adaptation is known as an acculturation process, which is a process by which changes happen in the beliefs or practices of an ethnic group as a result of a cultural encounter between two different cultures (Berry, 2005, 2019; Sam \& Berry, 2010).

Acculturation has a huge impact on immigrants. The effects of acculturation can be seen especially in food, clothing and leisure (games) (Yusoff, Samsuri, Ayob, \& Reza, 2019; Zhang et al., 2019). The effect of acculturation is not only visible on the outside but also the psychological and physical well-being of the immigrants themselves (Kovacev \& Shute, 2010; Lopez-Class et al., 2011; Rosenthal, 2018; Torres et al., 2012; Urzua et al., 2017). Several studies focusing on immigrant-related issues and their implications towards the mental aspect of their well-being helped to draw to this conclusion (Balidemaj \& Small, 2019; Beiser \& Hou, 2017; Cleary et al., 2018; Cooper et al., 2019; George et al., 2015; McCorkle, 2020; Schotte et al., 2018; Steel et al., 2017). Moreover, it was evident from past literatures that the immigrants as ethnic minority show difference in their focal psychology compared to the ethnic majority who live in the country (Akinsola, 2020; El-Bouhaddani et al., 2019; Masud, 2020; Nielsen et al., 2018).

Previous studies from a cultural heritage perspective on immigrant issues have found that immigrants who maintained their original cultural practices have experienced a positive effect on their psychosocial adjustment and well-being (Sun et al., 2020; Telzer et al., 2016). It was also discovered that the tendency of Malaysian immigrants to practise their own culture accounts for $6 \%$ of the variance in their emotional reactions towards the cultural heritage of their place of migration, Malaysia (Yusoff, Samsuri, Ayob, \& Reza, 2019). These findings are not only reflected in studies of immigrants to Malaysia but is also evident in studies on immigrants to other Asian and western countries. For instance, findings from in-depth interviews on food preference show that the Latino (from Dominican Republic, Mexico, or Puerto Rico) who migrated to the United States of America (US) still choose to eat food they have back at their home country (e.g., tortillas, tacos, ceviche). In addition, their children who grow up in the US also prefer food from their original culture despite being in the US from a very young age (Fuster et al., 2019).

On the other hand, country such as Singapore has been very accommodating towards the immigrants. This is evident from the existence of ethnic enclaves in the country to cater to the demands for the country's increased level of tourists. The representatives for ethnic enclaves in Singapore are the 'Chinatown, Kampong Street (representing the Malay culture), Little India, and Arab Street (representing the Muslims) (Kim et al., 2020). There is also a 'Koreatown' in Tanjong Pagar street in Singapore, which adopted Korean trends (i.e., food and fashion) since the early 2000s (Kim et al., 2020). This reflects the country's willingness to cater for the immigrant's needs and also to fit in with the 'Korean Wave' trends which has been on the rise since the increase of K-culture and K-pop and K-drama lovers. With this, Korean immigrants will most likely visit this town to have their meals and clothing, which will decrease the possibility for them to experience the local delicacies or purchase local fashion items. When the immigrants consume local products of the country they visited, including foreign music and movies, they are attaching the new cultural products to their original culture (Lee et al., 2020). These immigrants will develop the 'new' hybrid culture according to their own 'taste, values, and needs' (Jang \& Song, 2016, as cited in Lee et al., 
2020). This is a positive side because despite receiving a new cultural influence, the country's cultural ethos can be kept alive (Kaisii, 2017).

Moreover, Winkelman (1994) suggested four phases of trajectories to explain the cultural adaptation by new immigrants. The phases are, honeymoon, crisis period, adjustment, and acceptance and adaptation. During the first phase (honeymoon phase), newly migrated immigrants experience excitement and fascination with the new culture. During this phase, they tend to overlook problems which are insignificant and excited to explore new things. Meanwhile, the second phase of 'Crisis period' (or also known as 'culture shock') is a condition where they started to tune down on the excitement and experience disappointment after going through more major changes in their lives. In addition, they may feel overwhelmed and irritated by the difficulties they face in the foreign country they moved to and could possibility start giving rude remarks or making jokes (also called the 'fight back' period). During the third or 'Adjustment' phase, the newcomers learn to accept the culture and to change their negative attitude to a positive one. In the last phase of 'Acceptance and Adaptation', the newcomers feel 'at home' and become involved in activities and may enjoy some of the country's customs.

\section{Theoretical Framework: Visualization and Circumplex Model of Affect (Valence)}

This study used a visualisation approach to explore the emotions of the immigrants towards the Malay cultural heritage, which is the traditional culture of the ethnic majority in Malaysia. Through this visualisation approach, two key points are emphasised. The first is the reference to Gestalt's theory (Koffka, 1935; Kohler, 1938). This theory is used as a reference because visual perception towards something reflects on the emotional tendency of a person. This fact has been established by studies in the field of psychology that have attempted to understand perception (e.g. Curby \& Moerel, 2019; Dybala et al., 2020; Feldman, 2001; Guberman, 2017; Kałamała et al., 2017; Kimchi, 2000; Peterson \& Kimchi, 2013; Tétreault et al., 2020; Wagemans et al., 2012). Both humans and animals use visualisation in their daily life to process information from the environment, which is essential for survival. The process of visualisation involves not only the use of physical eyes but also biological and psychological aspects. This current study applied one of several of Gestalt's principles that is important in a visualisation approach, which is the Law of Past Experience. This principle is influential in the visualisation process. The emotional reaction of immigrants towards Malay cultural pictures depends on their experiences when they are in Malaysia. In other words, the longer they are in Malaysia, the more they are exposed to the Malay culture.

The second focus in this research is the measurement of the valence element, which is a subjective and fundamental emotional experience indicated by the emotional continuum of pleasantness and unpleasantness that an event or a thing triggers (Russell, 1991). The Circumplex Model of Affect, a model of emotion that states valence as a basic domain in the emotional structure of humans, has been much integrated into the conceptual framework of psychology (Barrett, 2006a, 2006b; Carr \& Incetas, 2018; Rolls, 1999; Russell, 2003; Styliadis et al., 2018).

Based on the two points stated above, one research question in this study is if the time frame of a one-year period in Malaysia can influence the emotional tendency of immigrants towards the cultural heritage in their place of migration? Second, among the items of the Malay cultural heritage (games, clothes or food), which has more impact on the immigrants? This research question addresses whether past experiences (Gestalt Theory of The Law of Past Experience) have significant implications in the experience of the emotional valence of a person (Bliss-Moreau et al., 2020; Posner et al., 2005; Russell, 2003). 


\section{Research Method}

\section{Study Participants and Study Locations}

The participants of this study were international graduate students at a public university in West Malaysia. Through convenient sampling, 119 international students who met the criteria agreed to participate in this study, which included having no vision problems or any background of psychological abnormality. Because this study involves the assessment towards the visualization of images, participants with visual impairments who were not aided by glasses or contact lenses were not allowed to participate. Besides that, participants in this study who have a spouse of Malaysian nationality or were born from mixed marriages (that is whether the mother or father was married to non-Malaysian citizens) were excluded from the study to avoid possible cultural bias. All participants come from different cultural backgrounds that were very different compared to the Malay culture - South Asia (42\%), West Asia (30\%) and Africa (28\%). A total of 49 participants (41\%) had lived in Malaysia for a year or more while $70(59 \%)$ had lived in Malaysia for less than a year. Participant ages ranged from 17 to 40 (mean age $27 \pm 6.6$ ). Most participants were male (n $=72,61 \%$ ).

\section{Study Procedure}

The protocol of this study was approved by the Institutional Review Board (IRB). Participants who agreed to participate in this study were required to fully understand the objectives and procedures of the study before signing the informed consent form. A copy of the relevant documents, which were the consent form and study details, were provided to the participants to be kept as a reference. Participants' welfare was considered by providing honorarium (money) as compensation for the time and energy given for this research. Participants were also allowed to withdraw from the study at any point of time.

The study was conducted on a cross-sectional basis in which participants were gathered in a lecture hall. Through the visualisation approach, participants were required to provide their emotional response towards the images of the Malay heritage projected from the screen by rating the Self-Assessment Manikin scale (Bradley \& Lang, 1994) (Figure 1). Participants were also required to provide their socio-demographic information and level of acculturation in the form provided (i.e., the Vancouver Index of Acculturation- VIA).

\section{Image Visualisation of Malay heritage}

Images of Malay heritage projected from the screen comprised of three different types of images from different categories (Figure 1), which were: 1) traditional Malay food-ketupat palas, 2) traditional Malay game - sepak raga, and 3) traditional Malay clothes -kebaya/baju Melayu. Experts in the field of Malay heritage consisting of two academic members and a cultural officer assessed the content validity of these images. Participants were instructed to evaluate the cultural heritage images mentioned above based on four options (Davis, 1992) below:

$1=$ not relevant

$2=$ somewhat relevant

$3=$ quite relevant (given as $\mathrm{X}$ ) 


\section{Yusoff, N.}

\section{4 = highly relevant (given as $\mathrm{X}$ )}

The content validity of each picture was shown by the Content Validity Index (CVI) by considering the X scores (i.e., from Score 3 and 4) obtained from each evaluator (Davis, 1992). The calculation is depicted as below:

\section{Number of $X$}

\section{Number of Evaluators}

In this study, all images had a score of one for the Individual Content Validity Index (ICVI). Thus, the images had good content validity (Davis, 1992). In addition, the Malay heritage items that were displayed in the photos had already been acknowledged as an ancestral heritage of the Malays, which are still being preserved (Department of National Heritage Malaysia, 2020).

Quality controls were considered, and all the pictures displayed were adjusted in terms of brightness and size to avoid technical bias. These images were also free of copyright. See Figure 1 below.

\section{Figure 1}

Malay Traditional Items

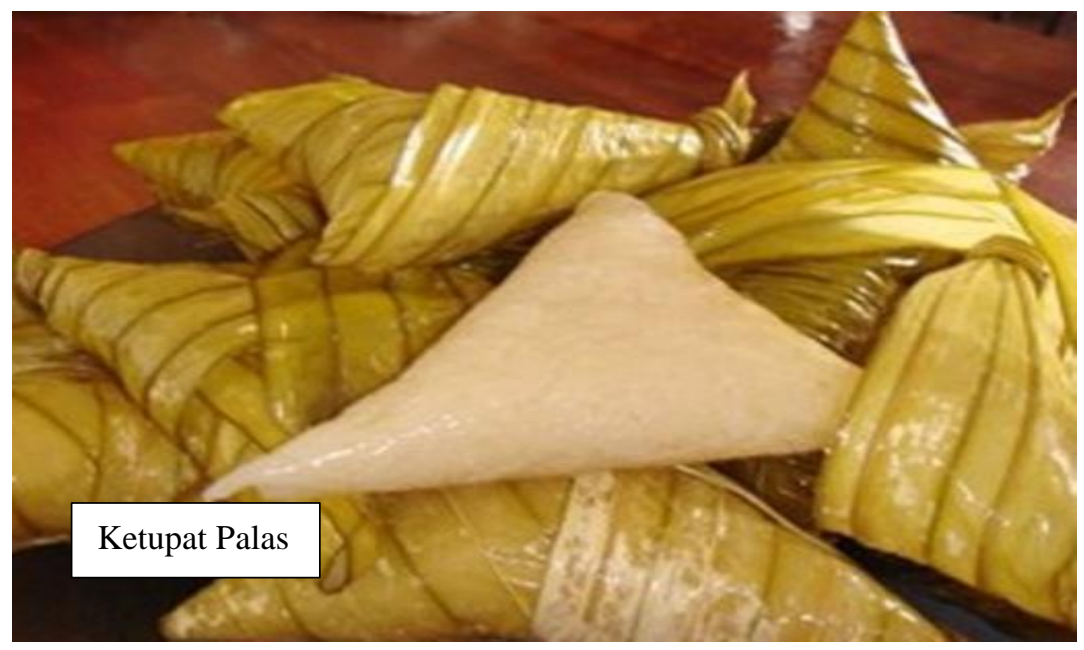




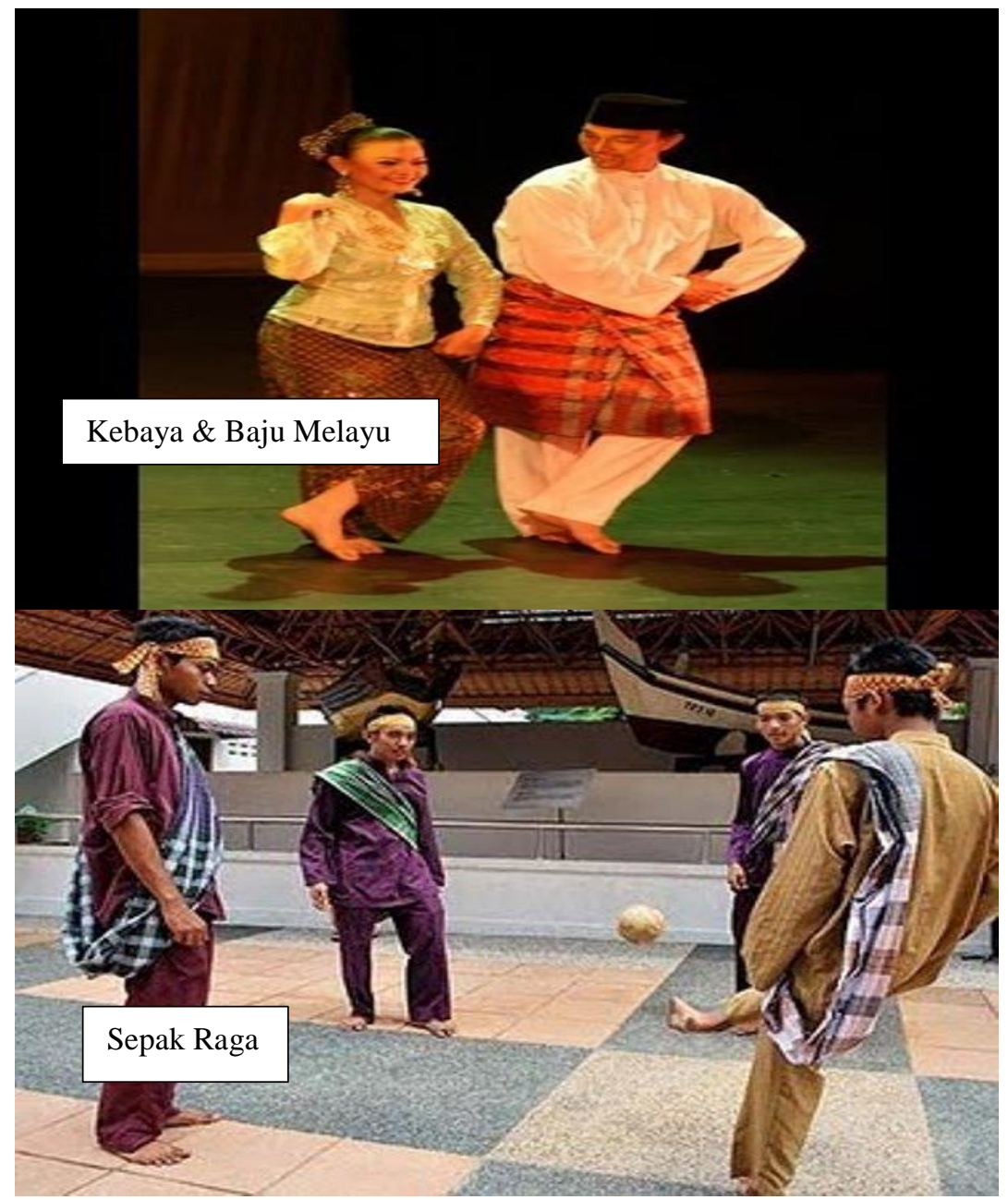

\section{Self-Assessment Manikin Scale}

The Self-Assessment Manikin Scale is a scale that measures emotional domains such as valence, arousal, and dominance (Bradley \& Lang, 1994). Because this scale is effective and is of low cost, it has been widely used in the study of emotions (Bynion \& Feldner 2017; Geethanjali et al., 2017; Li et al., 2019; Murdoch et al., 2019). This study focused on the element of valence, which is an element that refers to the internal emotional dimension that is positive (attraction) or negative (rejection) triggered by something, whether it is an object or not an object.

\section{Figure 2}

Emotional Continuum of Self-Assessment Manikin (SAM) for Valence - 1 (Unpleasantness/ Unhappy) to 9 (Pleasantness/Happy)

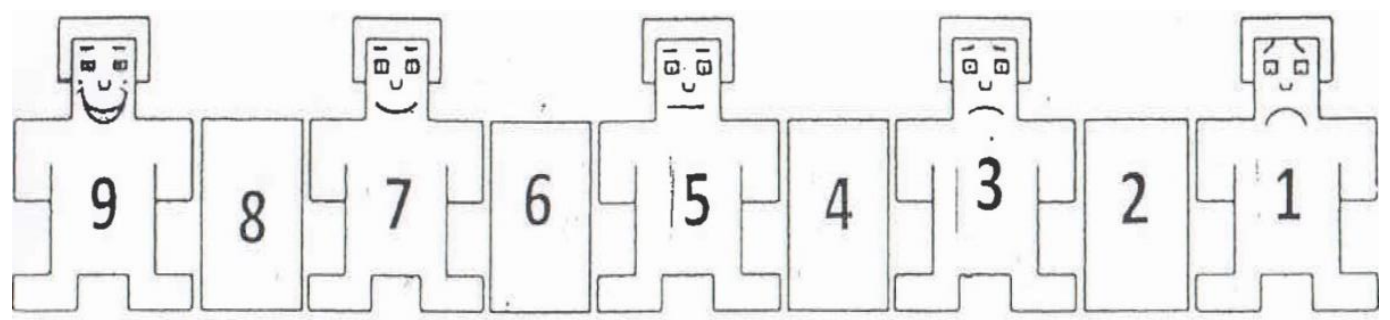


In this scale, participants were asked to provide feedback on their emotional state by rating an answer option ranging from one (that indicate unpleasant emotion or unhappiness) to nine (that indicate pleasant emotion or happy emotion) (Figure 2). Figures of facial expressions that indicate levels of pleasantness/happiness were included together with the answer option to help participants describe their emotions more accurately.

\section{Vancouver Index of Acculturation (VIA)}

The VIA is a standardised scale that measures the tendency of cultural practice among newcomers from two cultural views - 1) maintaining the old traditional practice and 2) practising the new tradition while living under a new (host) culture (Paulhus, 2013). This scale has 20 items that can be divided into two sections. The odd-numbered questions (10 items) are the questions that request participants to respond concerning their home cultural heritage. For example, "I often participate in my heritage cultural traditions". The remaining 10 questions (even-numbered items) request participants to respond with regard to their new settlement cultural heritage. For example, "I often participate in mainstream [Malay] cultural traditions". Some changes in the original even-numbered items were made to conform with the host culture, which is the Malay culture. For example, as indicated by the underlined word "I enjoy American entertainment (e.g., movies, music)" was replaced with "I enjoy Malay entertainment (e.g., movies, music)". The psychometric properties of VIA have been reported elsewhere (Ryder et al., 2000). In this study, the internal consistency of the scale was acceptable with a Cronbach's alpha of 0.89 .

\section{Statistical Analysis}

Data were analysed with the Statistical Package for the Social Sciences (SPSS) Version 23. The analysis of variance (ANOVA) for a two-way mixed design was carried out to determine the interaction effect between the emotional response from Malay cultural heritage items (three levels of between-subjects effect: 1) traditional game, 2) traditional clothes and 3) traditional food) AND the duration of living in Malaysia (two levels of the within-subjects effect: 1) less than a year and 2) a year or more). The degree of freedom of the F ratio was corrected (if any) according to the Huynh-Feldt method along with the assumption of sphericity. Other than that, the regression analysis was performed to determine the predictive value of the significant independent variable on the dependent variable as modelled.

\section{Results}

The analysis of variance of the two-way mixed design indicated a significant main effect for the three types of Malay cultural heritage (Table 1). The traditional Malay food indicated a higher emotional expression from the immigrants (Mean=6.6 \pm 2.1 ) as compared to the Malay traditional game $(M e a n=5.8 \pm 2.2)$ and clothes $($ Mean=6.4 \pm 1.8$)-[\mathrm{F}(1.70,229.72)=5.60, \mathrm{p}<0.05]$. However, an interaction effect between the Malay traditional items and the duration of staying in Malaysia was not detected $-[\mathrm{F}(1.70,229.72)=0.40, \mathrm{~ns}]$. 


\section{Table 1}

Interaction of Malay Cultural Heritage and Years of Living in Malaysia

\begin{tabular}{lcccc}
\hline & \multicolumn{2}{c}{ Main Effect* } & \multicolumn{2}{c}{ Interaction Effect } \\
\hline & $\mathrm{F}$ & $\mathrm{df}$ & $\mathrm{F}$ & $\mathrm{df}$ \\
\hline $\begin{array}{l}\text { Malay Cultural } \\
\text { Heritage }^{1} \text { X Duration } \\
\text { of living in Malaysia }\end{array}$ & 5.60 & 1.96 & 0.40 & 1.96 \\
\hline${ }^{1}{ }^{2}$ Within Subject Effect & & & & \\
\hline
\end{tabular}

${ }^{1}$ Within Subject Effect: (a) Traditional game, (b) Traditional clothes, (c) Traditional food

${ }^{2}$ Between Subject Effects: (a) less than a year (b) a year or more

$* p<0.05$

Pearson correlation was conducted to determine the correlation between Malay cultural heritage items, duration of staying in Malaysia and their tendency towards practising Malay culture (Table 2). Among other Malay traditional items, the emotional expression of immigrants towards Malay traditional food revealed a significant correlation with their tendency to practise the Malay culture ( $\mathrm{r}=0.20, \mathrm{p}<0.05)$. However, the duration of staying in Malaysia did not show any correlation with any Malay traditional items. The traditional Malay food was the only variable that had a significant correlation with another associated variable (i.e., a tendency towards practising the Malay culture. Thus, these variables were input into the regression model to determine the predictive value of the independent variable (i.e., a tendency towards practising the Malay culture) towards the emotional expression of the immigrants towards Malay traditional food (Table 3).

\section{Table 2}

Pearson Correlation ( $r$ ) between Malay Cultural Heritage and Associated Variables

\begin{tabular}{|c|c|c|}
\hline & $\begin{array}{c}\text { Duration of living in } \\
\text { Malaysia } \\
(\text { Mean=13.0; } \mathrm{SD}=18.4)\end{array}$ & $\begin{array}{c}\text { Tendency to practice Malay } \\
\text { tradition } \\
(\text { Mean=50.9; } \mathrm{SD}=14.0)\end{array}$ \\
\hline $\begin{array}{l}\text { Traditional game } \\
(\text { Mean }=5.8 ; \mathrm{SD}=2.2)\end{array}$ & 0.09 & 0.12 \\
\hline $\begin{array}{l}\text { Traditional clothes } \\
(\text { Mean }=6.4 ; \mathrm{SD}=1.8)\end{array}$ & 0.09 & 0.05 \\
\hline $\begin{array}{l}\text { Traditional food } \\
(\text { Mean=6.6; } \mathrm{SD}=2.1)\end{array}$ & 0.06 & $0.20 *$ \\
\hline
\end{tabular}

Through the 'enter method' that was performed in the regression analysis (Table 3), it was found that the tendency of immigrants to practice the Malay tradition (independent variable) explained $4 \%$ of the variance of immigrants' emotional expression towards Malay traditional food (dependent variable $)-(\beta=0.2, \mathrm{t}=2.1, \mathrm{p}<0.05)$. 


\section{Yusoff, N.}

Table 3

Prediction of Immigrants' Tendency to Practice the Malay Culture on the Emotional Expression of Malay Traditional Food

\begin{tabular}{lccccc}
\hline & $\mathrm{R}^{2}$ & $\begin{array}{c}\text { Standardised } \\
\text { Coefficient } \\
\text { Beta }\end{array}$ & df & $\mathrm{F}$ & $p$-value \\
\hline $\begin{array}{l}\text { Acculturation (tendency } \\
\text { towards Malay culture) }\end{array}$ & 0.04 & 0.2 & 1 & 4.6 & $0.03 *$ \\
\hline
\end{tabular}

$* p<0.05$

To understand the tendency of cultural practice (whether tendency towards practising own culture or tendency towards practising the Malay culture) during living in Malaysia, a paired t-test was performed with the one-year duration (less or more) as a cut-off (Table 4). The results revealed that both groups (i.e., immigrants living in Malaysia for less than a year and immigrants living in Malaysia for a year or more) had more of a tendency to maintain their tradition while living in the new settlement (i.e., Malaysia).

Table 4

Tendency of Cultural Practice and Years of Living in Malaysia

\begin{tabular}{lcccc}
\multicolumn{1}{c}{$\begin{array}{c}\text { Years of living in } \\
\text { Malaysia }\end{array}$} & $\begin{array}{c}\text { Tendency to } \\
\text { maintain their } \\
\text { own culture } \\
\text { (Mean, Standard } \\
\text { Deviation) }\end{array}$ & $\begin{array}{c}\text { Tendency to } \\
\text { practice Malay } \\
\text { culture (Mean, } \\
\text { Standard } \\
\text { Deviation) }\end{array}$ & $t$ & P-value \\
\hline $\begin{array}{l}\text { Less than a year } \\
(\mathrm{N}=70)\end{array}$ & $65.5 \pm 15.40$ & $50.8 \pm 15.12$ & 7.6 & $\mathrm{p}<0.001$ \\
$\begin{array}{l}\text { A year } \text { or more } \\
(\mathrm{N}=49)\end{array}$ & $65.4 \pm 16.9$ & $51.08 \pm 12.46$ & 5.5 & $\mathrm{p}<0.001$ \\
\hline
\end{tabular}

\section{Discussion}

This study determined a few factors which must be given attention. First, a closer look must be given to the elements of the Malay culture in a detailed study by looking at the elements of culture that were most affected during the adaptation of immigrants to the culture in a new country (Malaysia). At the same time, the effect of the duration of staying in the new country by the immigrants in the new cultural environment (Malaysia) is based on a one-year cut off period, as suggested by De Leersnyder (2017). Adaptation towards cultural elements is closely related to the factor of the duration of living in a place (or in this case, a country).

Immigrants tend to practise their own culture when the country their migrated to is accommodating for their cultural needs. For the case in Malaysia and Singapore, the immigrants feel welcomed because they can easily find the food, clothing, and leisure activities which are similar to those that can be found back in their home country. These were highlighted in the introduction with the given examples of the 'Koreatown' in Singapore (Kim et al., 2020) and cultural hybridity experienced in Malaysia and Indonesia (Lee et al., 2020). There are also other 
factors which were not explored in the present study, including the traditional values of the immigrants themselves, could influence whether they would assimilate with the country of migration or remain practising their original cultures without making any changes or adaptation.

This study proposes a research result that is more specific on the dimensions of acculturation (encounter and cultural adaptation) that immigrants in Malaysia experience. First and foremost is that the effect of acculturation varies according to the cultural elements. This study, in particular, found that traditional food element had the highest emotional reactions compared to the traditional clothing and traditional games elements. Reactions of immigrants towards traditional food were predicted by acculturation factors (tendency towards culture in a new place). Conversely, these acculturation factors were not found to influence the emotional reactions of immigrants towards traditional clothes and games.

These findings indicate that food elements are more affected in the process of acculturation compared to other elements of the Malay culture. Similar findings have been found in studies conducted among Malaysian ethnic minority, which is the Chinese ethnic group (Yusoff, Samsuri, Ayob, \& Teo, 2019). Based on this Yusoff, Samsuri, Ayob, \& Teo's (2019) findings, the Chinese ethnic minority, who is known to have a history of ancestors who migrated to Malaya several centuries ago, showed a higher emotional reaction towards images of traditional food compared to images of traditional clothing and the images of traditional games. This finding is also in line with Fuster et al.'s (2019) study on food practices among Latino immigrants in the US. They found these immigrants and their children who grow up in the US to prefer food from their home countries (Fuster et al., 2019).

Emotional aspects are largely related to food (e.g., Jones \& Herr, 2018; Mikhail \& Kring, 2019; Sinha, 2018; Ulrich-Lai et al., 2015; Yau \& Potenza, 2013; Yusoff, Samsuri, Ayob, \& Reza, 2019), that may be a justification for the high degree of immigrants' emotional reaction towards food images. De Leersnyder (2017) emphasised the assessment of acculturation from an emotional point of view, especially minority group emotions. According to her, changes in the minority group emotion occur as a result of contact with new cultures in a place. Involvement of a person (from a minority group) in a cultural practice is usually related to the emotional appropriateness of a person when being in a new place. Immigrants who are a minority group in Malaysia have undergone a contact phase with the ethnic majority (Malay ethnicity). In other words, this group of immigrants has been through life experiences in the Malay ethnic tradition. However, they still have the chance to choose the appropriate Malay tradition that suits their emotional atmosphere. This current study found that immigrants had more reactions towards the images of Malay traditional food compared to images of traditional clothes and traditional games (De Leersnyder, 2017).

The three-stage model that Pearson (1987) suggested can be used as a concept to explain the process of food acculturation that happens among these group of immigrants. According to Pearson (1987), acculturation is a cultural phenomenon that begins with the existence of a relationship or contact among different cultures. Thus, in this phase, immigrants undergo a new experience in a new place where they begin to be exposed to the diversity of traditional and nontraditional foods are available in the Malay community. The adaptation phase then follows this contact phase. During the adaptation phase, the group of immigrants begin to adapt to the new cultural environment. This means that they have shifted from the introduction phase towards traditional Malay food to a higher phase of adaptation. The framework of the relationship and adaptation concept can also be interpreted through the lens of Sam and Berry (2010). They emphasised that the adaptation of a social group towards the culture of another social group involves the acquisition of traditional beliefs and practices. This means that, in a cultural encounter, one party will be affected and will undergo socio-cultural change. However, after the introductory 
phase, these group of immigrants have taken a cultural action which is "choosing" to place themselves in "adaptation." In this regard, immigrants have chosen to adapt themselves more to the food element (at this time), compared to other elements such as traditional games and traditional clothing.

This fulfils the neuro-cultural interaction model addressed by Kitayama and Tompson (2010), in which before the formation of a neural system underlying a repetitive and voluntary (without coercion) cultural behaviour, a person must first choose the type of cultural practice that goes along with the goals he/she wants to achieve. The basis for this selection depends on macro or external ecology and social factors. The arrival of immigrants from various corners of the world who have different geographies and climates is an ecological factor while migration goals such as study, work and so on are social factors.

The periodic factors of being in Malaysia do not represent a significant predictor factor (due to the bias of the periodic distribution). Thus, the practices of the original culture are still rooted in these immigrants, who have lived for less than a year or more in the host country. This is based on the acculturation data, which found immigrants who lived in Malaysia for less than a year showed a greater tendency towards their own cultural practices (Mean $=65.3$; Standard Deviation $=16.86$ ) compared to the cultures in a new place $($ Mean $=51.1$; Standard Deviation $=12.46)-(\mathrm{t}=7.6, \mathrm{p}$ $<0.00)$. The same situation was found for immigrants who lived in Malaysia for a year or more where they also exhibited a greater tendency to practice their own culture (Mean $=65.5$; Standard Deviation $=15.39)$ than in new cultures $($ Mean $=50.79$; Standard Deviation $=15.13)-(\mathrm{t}=5.5, \mathrm{p}$ $<0.00)$. This fact explains clearly that immigrants are still inclined to retain their original culture, but at the same time, they are undergoing a process of adaptation with the local traditional culture to which they migrated.

Nevertheless, the formation of a cultural practice that is characterised by repetitive and voluntary behaviour is not a matter which can be done in a short time (Berges Puyo, 2020). This is because this formation involves the development of a neural system underlying cultural behaviour. In Yusoff, Samsuri, Ayob, and Teo (2019), the emotional similarity shown by an ethnic minority can explain that the actual process of acculturation takes a very long time. This Yusoff, Samsuri, Ayob, and Teo's (2019) study, which was conducted among Chinese ethnic minority in Malaysia, provided a long history of ethnicity in Malaysian history as they were employed as labourers in the mines industry and involved in trading activities, and growing the generation through intermarriage (Ching \& McKenna, 1990; Gurer, 2019; Othman, 2002; Shafie \& Zainudin, 2000). This long process of acculturation (from the 19th century up to this century) has produced a Chinese community that practices Malay culture, which is evident in many aspects of their lives. The best example of how the Chinese ethnic minority that has a history of migration in the past and has blended with the culture of Malay ethnic majority can be seen in the village of Tirok in Terengganu, Malaysia (Tan, 2011) and the village of Pasir Parit, Pasir Mas, Kelantan, Malaysia (Zainal Abidin et al., 2016). They have undergone socio-cultural processes with contact and adaptation that eventually form a social group that is acculturated from the majority social culture to which they migrated. Hence, it is not surprising that this study did not find major contributions to the living duration of immigrants in Malaysia towards the culture-emotional tendency in a new place. The time frame was too small.

This study has several limitations. First, the small number of study participants needs to be increased in future studies. Second, the duration of the participants living in Malaysia was short. The sample included a high percentage of immigrants who lived in Malaysia for less than a year (59\%), and 38\% lived in Malaysia for a year or more (but less than five years). The remaining 3\% were immigrants who had lived in Malaysia for more than five years. Thus, no immigrants had 
lived in Malaysia for more than ten years - a period considered rational for changes in practices and beliefs. Future studies should collect data for more than one time-point to gain an estimation for the period of time needed by immigrants to live in a new environment (or in this case, a new country) in order to adapt with different phases of cultural adaptation, as suggested by Winkelman's (1994) trajectories of cultural adaptation. It is important for immigrants to get from the honeymoon phase of a culture to accepting and adapting the culture.

\section{Conclusion}

Periodic factors and the emotional properties of the cultural elements provide significant implication in the emotional appearance of the immigrants to adapt to the new cultural environment. According to De Leersnyder (2017), acculturation that is measured from an emotional aspect among individuals experiencing cultural encounter can occur as early as a year after they are in a new place. But as indicated from the present study, regardless of the period of living in Malaysia, the immigrants tend to retain their own tradition or culture. This should be reflected positively because it gives a positive implication towards the well-being of the immigrants, as discussed earlier on (Sun et al., 2020; Telzer et al., 2016).

Furthermore, the results of this study suggest that acculturation depends on the elements of the new culture, particularly the 'food' element. 'Food' has the potential to have an accelerated effect on acculturation compared to other cultural elements. The cultural hybridity is an important and encouraging factor for the immigrants to continue practicing their original cultural preference. As discussed in the earlier sections, Malaysia is a multicultural country, with the influence of past colonisation. This increases the chance for Malaysians to be more accommodating towards a person who practices a different culture, perhaps to the point that they could fit in without making major changes to their original practices.

As the implication, the countries cultural practices are important determinants of whether the immigrants would feel belong and continue living in a country for a longer duration. From the findings, it seems that Malaysia is a country which is very welcoming towards immigrants due to our cultural hybridity. This is an element that should be retained because being able to practice a culture that one is familiar with also means the country is able to keep the local culture 'alive' while being more welcoming towards tourists from across the globe.

\section{Acknowledgments}

Ministry of Education, Malaysia for the Fundamental Research Grant Scheme 203.PPSP.6171204 and the Universiti Sains Malaysia for research facilities.

\section{Declaration of Conflict of Interest}

The authors of this manuscript declare they have no conflict of interest concerning its drafting, publication, or application.

\section{References}

Akbar, J. (2010). Mengunyah sejarah ketupat [Chew: The history of rhubarb]. http://historia.id/modern/mengunyah-sejarah ketupat 
Akinsola, I. T. (2020). Nollywood Reception Preferences among Selected Multilingual Nigerian Undergraduates in the University of Ibadan: Does Ethnicity Still Matter?. American Journal of Qualitative Research, 4(1), 38-48. https://doi.org/10.29333/ajqr/8210

Alexanderll, J. (2006). Malaysia Brunei \& Singapore. New Holland Publishers.

Balidemaj, A., \& Small, M. (2019). The effects of ethnic identity and acculturation in mental health of immigrants: A literature review. International Journal of Social Psychiatry, 65(7-8), 643-655. https://doi.org/10.1177/0020764019867994

Barnard, T. P. (2004). Contesting Malayness: Malay identity across boundaries. Singapore University Press.

Barrett, L. F. (2006a). Are emotions natural kinds? Perspectives on Psychological Science, 1(1), 28-58. https://doi.org/10.1111/j.1745-6916.2006.00003.x

Barrett, L. F. (2006b). Solving the emotion paradox: categorisation and the experience of emotion. Personality \& Social Psychology Review, 10(1), 20-46. https://doi.org/10.1207/s15327957 pspr1001_2

Beiser, M., \& Hou, F. (2017). Predictors of positive mental health among refugees: Results from Canada's General Social Survey. Transcultural Psychiatry, 54(5-6), 675-695. https://doi.org/10.1177/ 1363461517724985

Berges Puyo, J. (2020). A Value and Character Educational Model: Repercussions for Students, Teachers, and Families. Journal of Culture and Values in Education. https://doi.org/10.46303/jcve.2020.7

Berry, J. W. (2005). Acculturation: Living successfully in two cultures. International Journal of Intercultural Relations, 29(6), 697-712. https://doi.org/10.1016/j.ijintrel.2005.07.013

Berry, J. W. (2019). Acculturation: A personal journey across cultures (Elements in psychology and culture). Cambridge University Press.

Bliss-Moreau, E., Williams, L. A., \& Santistevan, A. C. (2020). The immutability of valence and arousal in the foundation of emotion. Emotion, 20(6), 993-1004. https://doi.org/10.1037/emo0000606

Bradley, M. M., \& Lang, P. J. (1994). Measuring emotion: The self-assessment manikin and the semantic differential. Journal of Behavior Therapy \& Experimental Psychiatry, 25(1), 4959. https://doi.org/10.1016/0005-7916(94)90063-9

Bynion, T.-M., \& Feldner, M. T. (2017). Self-assessment Manikin. In T. Zeigler-Hill \& T. K. Shackelford (Eds.), Encyclopedia of personality \& individual differences (pp. 167-175). Springer International Publishing.

Carr, E. R., \& Incetas, Y. (2018). Perceptions and Experiences of Non-Muslim Minority Students on the Muslim Image. Journal of Ethnic and Cultural Studies, 5(2), 4352. http://dx.doi.org/10.29333/ejecs/107

Ching, F. Y., \& McKenna, R. B. (1990). The Kuomintang Movement in British Malaya, 1912-1949. The University of Hawaii Press

Cleary, S. D., Snead, R., Dietz-Chavez, D., Rivera, I., \& Edberg, M. C. (2018). Immigrant trauma and mental health outcomes among Latino youth. Journal of Immigrant and Minority Health, 20(5), 1053-1059. https://doi.org/10.1007/s10903-017-0673-6

Cooper, S., Enticott, J. C., Shawyer, F., \& Meadows, G. (2019). Determinants of mental illness among humanitarian migrants: Longitudinal analysis of findings from the first three waves of a large cohort study. Frontiers in Psychiatry, 10. https://doi.org/ $10.3389 /$ fpsyt.2019.00545

Curby, K. M., \& Moerel, D. (2019). Behind the face of holistic perception: Holistic processing of Gestalt stimuli and faces recruit overlapping perceptual mechanisms. Attention, 
Perception, \& Psychophysics, 81(8), 2873-2880. https://doi.org/10.3758/s13414-01901749

Davis, L. (1992). Instrument review: Getting the most from your panel of experts. Applied Nursing Research, 5, 194-197. https://doi.org/10.1016/S0897-1897(05)80008-4

De Leersnyder, J. (2017). Emotional acculturation: A first review. Current Opinion in Psychology, 17, 67-73. https://doi.org/10.1016/j.copsyc.2017.06.007

Department of Malaysian Immigration.

(2016). https://www.imi.gov.my/portal2017/index.php/ms/

Department of National Art and Culture, Malaysia. (2019). Traditional games. http://jkkn.gov.my/ ms/traditional-games

Department of National Heritage Malaysia. (2020). Perisytiharan warisan kebangsaan [Declaration of national heritage 2015]. https://www.hrdnet.com.my/department-ofnational-heritage.html

Department of Statistics Malaysia. (2020). Population projection (Revised), Malaysia 2010-2040. https://www.dosm.gov.my/v1/index.php?r=column/cthemeByCat\&cat=118\&bul_id=Y3k wU2tSNVFDOWp1YmtZYnhUeVBEdz09\&menu_id=L0pheU43NWJwRWVSZklWdzQ 4TlhUUT09.

Dybala, M. P., Butterfield, J. K., Hendren-Santiago, B. K., \& Hara, M. (2020). Pancreatic islets and Gestalt principles. Diabetes, 69(9), 1864-1874. https://doi.org/10.2337/db20-0304

El-Bouhaddani, S., van Domburgh, L., Schaefer, B., Doreleijers, T. A. H., \& Veling, W. (2019). Psychotic experiences among ethnic majority and minority adolescents and the role of discrimination and ethnic identity. Social Psychiatry \& Psychiatric Epidemiology, 54(3), 343-353. https://doi.org/10.1007/s00127-019-01658-1

Feldman, J. (2001). Bayesian contour integration. Perception \& Psychophysics, 63(7), 1171-1182. https://doi.org/10.3758/BF03194532

Fuller, T. (2000, March 2). In era of t-shirts, kurung survives: Malaysians' garment of choice. The New York Times. https://www.nytimes.com/2000/03/02/news/in-era-of-tshirts-kurungsurvives-malaysians-garment-of-choice.html

Fuster, M., Weindorf, S., Mateo, K. F., Barata-Cavalcanti, O., \& Leung, M. M. (2019). "It's Sort Of, Like, in My Family's Blood": Exploring Latino pre-adolescent children and their parents' perceived cultural influences on food practices. Ecology of Food \& Nutrition, 58(6), 620-636. https://doi.org/10.1080/03670244.2019.1652819

Geethanjali, B., Adalarasu, K., Hemapraba, A., Kumar, S. P., \& Rajasekeran, R. (2017). Emotion analysis using SAM (Self-Assessment Manikin) scale. Biomedical Research, 28(Special Issue), 18-24.

George, U., Thomson, M. S., Chaze, F., \& Guruge, S. (2015). Immigrant mental health, a public health issue: Looking back and moving forward. International Journal of Environmental Research \& Public Health, 1(10), 13624-13648. https://doi.org/10.3390/ijerph121013624

Guberman, S. (2017). Gestalt Theory rearranged: Back to Wertheimer. Frontiers in Psychology, 11(8), 1782. https://doi.org/10.3389/fpsyg.2017.01782

Gurer, C. (2019). Refugee Perspectives on Integration in Germany. American Journal of Qualitative Research, 3(2), 52-70. https://doi.org/10.29333/ajqr/6433

Halimi, A. J. (2008). Sejarah dan tamadun bangsa Melayu [History and civilization of the Malays]. Utusan Publication.

Ihsan, S. L. A. (2009, September 16). Trends: For all occasions. New Straits Times. https://web.archive.org/web/20100515085307/http://www.nst.com.my/Current_News/NS T/articles/20090916093912/Article/index_html 
Jang, W., \& Song, J. E. (2016). The glocal culture and the Korean wave. Cultural Contents Research, 8, 7-34. http://dx.doi.org/10.34227/tjocc.2016.8.7

Jones, A. C., \& Herr, N. R. (2018). Emotion differentiation mediates the association between emotion regulation difficulties and caloric intake. Eating Behaviours, 29, 35-40. https://doi.org/10.1016/j.eatbeh.2018.02.003.

Kaisii, A. (2017). Globalization, hybridization and cultural invasion: Korean wave in India's North East. Asian Communication Research, 14, 10-35.

Kałamała, P., Sadowska, A., Ordziniak, W., \& Chuderski, A. (2017). Gestalt effects in visual working memory. Experimental Psychology, 64(1), 5-13. https://doi.org/10.1027/16183169/a000346

Kim, J., Kim, S. M., \& Suh, S. C. (2020). Koreatowns: Exploring the economics, politics, and identities of Korean spatial formation. Lexington Books.

Kimchi, R. (2000). The perceptual organisation of visual objects: A microgenetic analysis. Vision Research, 40(10-12), 1333-1347. https://doi.org/10.1016/S0042-6989(00)00027-4

Kitayama, S., \& Tompson, S. (2010). Envisioning the future of cultural neuroscience. Asian Journal of Social Psychology, 13(2), 92-101. https://doi.org/10.1111/j.1467839X.2010.01304.x

Koffka, K. (1935). Principles of Gestalt psychology. Harcourt.

Kohler, W. (1938). Physical Gestalten. In W. D. Ellis (Ed.), A sourcebook of Gestalt psychology (pp. 17-54). Routledge \& Kegan Paul.

Kovacev, L., \& Shute, R. (2010). Acculturation and social support in relation to psychosocial adjustment of adolescent refugees resettled in Australia. International Journal of Behavioral Development, 28(3), 259. https://doi.org/10.1080/01650250344000497

Lee, Y. L., Jung, M., Nathan, R. J., \& Chung, J.-E. (2020). Cross-national study on the perception of the Korean wave and cultural hybridity in Indonesia and Malaysia using discourse on social media. Sustainability, 12, 6072. https://doi.org/10.3390/su12156072

Li, X., Zhang, G., Zhou, C., \& Wang, X. (2019). Negative emotional state slows down movement speed: Behavioral and neural evidence. Peer J, 7, e7591. https://doi.org/10.7717/peerj.7591

Lopez-Class, M., Castro, F. G., \& Ramirez, A. G. (2011). Conceptions of acculturation: A review and statement of critical issues. Social Science \& Medicine, 72(9), 1555-62. https://doi.org/10. 1016/j.socscimed.2011.03.011

Masud, M. M. (2020). International Student Migration and Polymedia: The Use of Communication Media by Bangladeshi Students in Germany. Research in Social Sciences and Technology, 5(3), 95-110. https://doi.org/10.46303/ressat.05.03.5

McCorkle, W. (2020). Problematizing Immigration Restrictions during COVID-19 in the Social Studies Classroom. Research in Social Sciences and Technology, 5(3), 1-24. https://doi.org/10.46303/ressat.05.03.1

Mikhail, M. E., \& Kring, A. M. (2019). Emotion regulation strategy use and eating disorder symptoms in daily life. Eating Behaviours, 34, 101315. https://doi.org/10.1016/j.eatbeh.2019.101315.

Milner, A. (2010). The Malays (The peoples of south-east Asia and the Pacific). Wiley-Blackwell. Murdoch, M., Partin, M. R., Vang, D., \& Kehle-Forbes, S. M. (2019). The psychological risk of minimal risk activities: A pre- and posttest study using the Self-Asessment Manikin. Journal of Empirical Research on Human Research Ethics, 14(1), 15-22. https://doi.org/10.1177/1556264618810302.

Nielsen, T. R., Segers, K., Vanderaspoilden, V., Bekkhus-Wetterberg, P., Minthon, L., Pissiota, A., Bjorklof, G. H., Beinhoff, U., Tsolaki, M., Gkioka, M., \& Wademar, G. (2018). 
Performance of middle-aged and elderly European minority and majority populations on a Cross-Cultural Neuropsychological Test Battery (CNTB). Clinical Neuropsychology, 32(8), 1411-1430. https://doi.org/10.1080/13854046.2018.1430256.

Othman, I. (2002). Sejarah Malaysia (1800-1963) [History of Malaysia 1800-1963]. Utusan Publications.

Paulhus, D. L. (2013). Vancouver Index of Acculturation (VIA) - Measurement instrument database for the social science. Retrieved October 17, 2020 from https://www.midss.org/sites/default/ files/via.american.pdf

Pearson, S. (1987). Ethnic studies at Chicago: 1905-45. University of Illinois Press.

Peterson, M. A., \& Kimchi, R. (2013). Perceptual organisation in vision. In D. Reisberg (Ed.), Oxford handbook of cognitive psychology (pp. 9-31). Oxford University Press.

Posner, J., Russell, J. A., \& Peterson, B. S. (2005). The Circumplex Model of Affect: An integrative approach to affective neuroscience, cognitive development, and psychopathology. Development and Psychopathology, 17(3), 715-34. https://doi.org/10.1017/ S0954579405050340

Punitha, S., \& Kumaran, S. (2014). Cultural assimilation among Malays and Indians in Malaysia. Journal of Indian Culture 7 Civilization, 1, 34-45.

Rolls, E. T. (1999). The brain and emotion. Oxford University Press.

Rosenthal, T. (2018). Immigration and acculturation: Impact on health and well-being of immigrants. Current Hypertension Report, 20(8), 70. https://doi.org/10.1007/s11906-0180872-0

Rostam, K. (1984). Penduduk Malaysia. Nurin Enterprise.

Russell, J. A. (1991). Culture and the categorisation of emotions. Psychological Bulletin, 110, 426450. https://doi.org/10.1037/0033-2909.110.3.426

Russell, J. A. (2003). Core affect and the psychological construction of emotion. Psychological Review, 110, 145-172. https://doi.org/10.1037/0033-295x.110.1.145.

Ryder, A. G., Alden, L., \& Paulhus, D. L. (2000). Is acculturation unidimensional or bidimensional? A head-to-head comparison in the prediction of demographics, personality, self-identity, and adjustment. Journal of Personality \& Social Psychology, 79(1), 49-65. https://doi.org/10.1037//0022-3514.79.1.49

Sam, D. L., \& Berry, J. W. (2010). Acculturation when individuals and groups of different cultural backgrounds meet. Perspectives on Psychological Science, 5(4), 472-481. https://doi.org/10.1177/1745691610373075

Schotte, K., Stanat, P., \& Edele, A. (2018). Is integration always most adaptive? The role of cultural identity in academic achievement and in psychological adaptation of immigrant students in Germany. Journal of Youth Adolescent, 47(1), 16-37. https://doi.org/10.1007/s10964-0170737-x

Shafie, F., \& Zainudin, R. (2000). Sejarah Malaysia [History of Malaysia]. Penerbit Fajar Bakti Sdn. Bhd.

Sinha, R. (2018). Role of addiction and stress neurobiology on food intake and obesity. Biological Psychology. 131, 5-13. https://doi.org/10.1016/j.biopsycho.2017.05.001

Steel, J. L., Dunlavy, A. C., Harding, C. E., \& Theorell, T. (2017). The psychological consequences of pre-emigration trauma and post-migration stress in refugees and immigrants from Africa. Journal of Immigrants \& Minority Health, 9(3), 523-532. https://doi.org/10.1007/s10903016-0478-z 
Styliadis, C., Loannides, A. A., Bamidis, P. D., \& Papadelis, C. (2018). Mapping the spatiotemporal evolution of emotional processing: A MEG study across arousal and valence dimensions. Frontiers in Human Neuroscience, 12, 322. https://doi.org/10.3389/fnhum.2018.00322

Sun, Q., Geeraert, N., \& Simpson, A. (2020). Never mind the acculturation gap: Migrant youth's well-being benefit when they retain their heritage culture, but their parents adopt the settlement culture. Journal of Youth \& Adolescent, 49(2), 520-533. https://doi.org/10.1007/s10964-019-01160-6

Tan, Y. S. (2011). Akulturasi peranakan Cina di Tirok, Terengganu [Acculturation of 'peranakan Chinese' in Tirok, Terengganu]. Jurnal Terjemahan Alam dan Tamadun Melayu, 2(2), 151162. http://pkukmweb.ukm.my/terjemah

Telzer, E. H., Yuen, C., Gonzales, N., \& Fuligni, A.J. (2016). Filling gaps in the acculturation gapdistress model: Heritage cultural maintenance and adjustment in Mexican-American families. Journal of Youth \& Adolescent. 45(7), 1412-25. https://doi.org/10.1007/s10964015-0408-8

Tétreault, S., Bétrisey, C., Brisset, C., Gulfi, A., Schaer, M., Leanza, Y., \& Kühne, N. (2020). Intercultural Experiences Prior to the Educational Program: Occupational Therapy and Social Work Students. Journal of Culture and Values in Education. https://doi.org/10.46303/jcve.2020.6

Torres, L., Driscoll, M. W., \& Voell, M. (2012). Discrimination, acculturation, acculturative stress, and Latino psychological distress: A Moderated Mediational Model. Cultural Diversity \& Ethnicity Minority Psychology, 18(1), 17-25. https://doi.org/10.1037/a0026710

Ulrich-Lai, Y. M., Fulton, S., Wilson, M., Petrovich, G., \& Rinaman, L. (2015). Stress exposure, food intake and emotional state. Stress, 8(4), 381-99. https://doi.org/10.3109/10253890.2015.1062981

Urzua, A., Ferrer, R., Canales G. V., Nunez, A. D., Ravanal, L. I., \& Tabilo, P. B. (2017). The influence of acculturation strategies in quality of life by immigrants in Northern Chile. Quality of Life Research, 26, 717-726. https://doi.org/10.1007/s11136-016-1470-8

Wagemans, J., Elder, J. H., Kubovy, M., Palmer, S. E., Peterson, M. A., Singh, M., \& von der Heydt, R. (2012). A century of Gestalt psychology in visual perception: I. Perceptual grouping and figure-ground organisation. Psychological Bulletin, 138(6), 1172-1217. https://doi.org/10.1037/a0029333

Winkelman, M. (1994). Cultural shock and adaptation. Journal of Counselling \& Development 73(2), 121-126. https://doi.org/10.1002/j.1556-6676.1994.tb01723.x

Wolters, O. W. (1999). History, culture, and region in Southeast Asian perspectives. Cornell University Southeast Asia Program Publications.

Yau, Y. H., \& Potenza, M. N. (2013). Stress and eating behaviours. Minerva Endocrinology, 38(3), 255-267. PMC4214609.

Yusoff, N., Samsuri, N., Ayob, S., \& Reza, F. (2019). Visualisation of Malay traditional food: Emotional expression of the immigrants in Malaysia. GeoJournal of Tourism \& Geosites, 26(3), 905-915. https://doi.org/10.30892/gtg.26318-406

Yusoff, N., Samsuri, N., Ayob, S., \& Teo, Y. C. (2019). Emotional expression of the Malaysian Chinese towards the Malay cultural heritage visualisation. Journal of Ethnic \& Cultural Studies. 6(3), 53-63. http://dx.doi.org/10.29333/ejecs/259

Zainal Abidin, Z. H., Habidin, N. F., Yusof, M. Y., Hassan, P., Yaacob, H. R., Yaacob, M., \& Noh, A. M. (2016). Assimilation of the Malay culture towards the straights of Chinese community in the State of Kelantan: Study in Kampung Pasir Parit, Chetok, Pasir Mas, 
Kelantan. International Journal of Academic Research in Business \& Social Sciences, 6(11), 145-60. https://doi.org/10.6007/IJARBSS/v6-i11/2372

Zhang, Q., Liu, R., Diggs, L. A., Wang, Y., \& Ling, L. (2019). Does acculturation affect the dietary intakes and body weight status of children of immigrants in the U.S. and other developed countries? A Systematic Review. Ethnicity \& Health, 24(1), 73-93. https://doi.org/10.1080/ 13557858.2017.1315365

\section{Note on Contributors}

Nasir Yusoff is a Senior Lecturer at School of Medical Sciences, Universiti Sains Malaysia. He obtained PhD from University of Malaya, Kuala Lumpur, Malaysia with specialization in health psychology. He went to University of Chicago in 2012 to learn social neuroscience. His main research interest is social and cultural neuroscience specifically looking at the neuro-emotion interaction in social issues and cultural diversity.

Hue San Kuay is a Psychology Lecturer at School of Medical Sciences, Universiti Sains Malaysia, Malaysia. She completed her PhD in Psychology at Durham University, United Kingdom, specialising on aggression perpetrated by adolescents within the family, as well as culture diversity in community development. Her main research interests include adolescent's aggressive behaviour and culture underpinning in human development

Sabarisah Hashim is a Senior Lecturer at School of Medical Sciences, Universiti Sains Malaysia. She was awarded with PhD degree from University of Malaya, Kuala Lumpur, Malaysia in 2014 with specialization in community health and culture development. She had involved with a lot of community works around the country especially in providing social service to the disadvantaged people.

Faruque Reza is a Senior Medical Lecturer at School of Medical Sciences, Universiti Sains Malaysia, Malaysia. Awarded with PhD in 2000 from University of Japan, he is a dedicated lecturer in the area of electrophysiology and human psychology. His work has been published in many outstanding journals in the area of medical and health, as well as psychology and humanity. 